\title{
Public participation in watershed management: International practices for inclusiveness is
}

\author{
Patricia E. (Ellie) Perkins * \\ Faculty of Environmental Studies, York University, Toronto, Canada M3J 1P3
}

\section{A R T I C L E I N F O}

\section{Article history:}

Received 6 January 2009

Accepted 27 February 2010

Available online 3 March 2010

\section{Keywords:}

Watershed management

Public participation

Participatory governance

Gender and environmental management

Water and social equity

Democratic participation

\begin{abstract}
A B S T R A C T
This paper outlines a number of examples from around the world of participatory processes for watershed decision-making, and discusses how they work, why they are important, their social and ecological potential, and the practical details of how to start, expand and develop them. Because of longstanding power differentials in all societies along gender, class and ethnic lines, equitable public participation requires the recognition that different members of society have different kinds of relationships with the environment in general, and with water in particular. From a range of political perspectives, inclusive participatory governance processes have many benefits.

The author has recently completed a 5 year project linking universities and NGOs in Brazil and Canada to develop methods of broadening public engagement in local watershed management committees, with a special focus on gender and marginalized communities. The innovative environmental education and multi-lingual international public engagement practices of the Centre for Socio-Environmental Knowledge and Care of the La Plata Basin (which spans Brazil, Argentina, Uruguay, Paraguay and Bolivia) are also discussed in this paper.
\end{abstract}

(c) 2010 Elsevier Ltd. All rights reserved.

\section{Introduction}

Broad public participation is essential for sustainable watershed management, which is recognized in a wide range of policy statements, academic papers, and activist programmes world-wide. To cite just a few examples:

Principle 10 of the Rio Declaration on Environment and Development emphasized that citizens should have access to information and opportunities to participate in environmental decisionmaking processes (UN, 1992). The European Union has stressed public consultation, especially on environmental issues, in its policies and documents such as the Aarhus Convention, the Fifth Environment Action Programme of 1993 (EC, 1993) and the Sixth Environment Action Programme of 2002 (EC, 2002a). ${ }^{1}$ Europe's

\footnotetext{
Prepared for presentation and discussion at the Regional Meeting on Water in the Mediterranean Basin October 9-11, 2008, Near East University - Lefkosa, Northern Cyprus.

* Tel.: +1 416736 2100x22632; fax: +1 4167365679 .

E-mail address: esperk@yorku.ca

1 The fifth environment action programme includes, as one of its two major principles, that "only by replacing the command-and-control approach with shared responsibility between the various actors, e.g. governments, industry and the public, can commitment to agreed measures be achieved" (EC, 1993, p. 1). The sixth environment action programme includes as one of its five main action items, "Stimulation of participation and action of all actors from business to citizens, NGOs and social partners - through better and more accessible information on the environment and joint work on solutions" (EC, 2002a, p. 1).
}

Water Framework Directive (WFD) of 2000 directly integrated public participation in its requirements, and guidance documents for the implementation of the WFD are quite specific in outlining how to organize and carry out public participation processes (EC, 2000; van den Hove, 2003; Kenyon, 2003). ${ }^{2}$ The World Bank and other international agencies have also emphasized public participation in development projects (Kapoor, 2001; World Bank, 1996).

Grassroots initiatives from citizen budgeting to the World Social Forum call for more direct, democratic public involvement in decision-making at the local and national government levels, and also in global organizing. Recent examples of participatory processes within popular movement organizing include the Zapatistas' use of the internet to mobilize international support and conduct referenda (Zapatistas in Cyberspace, 2003) and the people's plebiscite in Tambogrande, Peru on June 2, 2002 where nearly 27,000 local people voted and $94 \%$ opposed the expansion plans of the Canadian firm Manhattan Mining, which led to the firm's retraction of its plans, citing shareholder concerns (Gedicks, 2005; Christian Aid, 2005, p. 33-34).

\footnotetext{
2 The water framework directive states, “Member States shall encourage the active involvement of all interested parties in the implementation of this Directive, in particular in the production, review and updating of the river basin management plans. Member States shall ensure that, for each river basin district, they publish and make available (information and plans) for comments (by) the public" (EC, 2000 Article 14). The Guidelines document on public participation for the WFD includes detailed comments on the use of Citizens' Juries (EC, 2002b).
} 
An extensive ecological economics and political ecology literature provides theoretical grounding for the wider use of consultative decision processes (Wilson and Howarth, 2002; Perkins, 2003; Munda, 1995; Sagoff, 1998; O'Connor, 2000; Holland, 1997; van den Hove, 2000; Faucheux and Hue, 2001). Political scientists and planners write about the motivations, complexities, and mechanics of public involvement in decision-making (Young, 2000; Nagel, 1987; Sanders, 1997; Steenbergen, 1994; Innes and Booher, 2004; Davies et al., 2006). Practice-based articles outline various ways for governments to conduct public participation processes, case studies of their uses and outcomes, and how to tailor specific processes to particular situations (Frontiers 2, 2003; Renn et al., 1995; Gregory and Slovic, 1997; De Marchi et al., 2001, 2000; Aldred and Jacobs, 2000; Fischer, 1993; Caddy, 2005). These formal consultative processes, which are summarized in Table 1 , range from public meetings and hearings to citizens' panels and juries, multi-stakeholder committees, "discourse-based valuation" (DBV) processes, and "deliberative multi-criteria mapping" exercises (Smith, 1999; Rowe and Frewer, 2005).

However, many progressive activists and scholars also critique "democratization" and "public participation" in environmental and development policy, pointing out that it both hides and perpetuates deep socio-political inequities (Gujit and Shah, 1998; Naples, 1998; Lister, 1997; Cooke and Kothari, 2001; Fraser, 1993; Fung, 2004; Kapoor, 2005; Kapoor, 2008). These inequities are evidenced in the minimal participation by women, and by lower-class or otherwise marginalized people, in public processes which are ostensibly meant to represent everyone in making public decisions which affect everyone - and often have the gravest impacts on the lives of those who participate least (Moraes and Perkins, 2007).

This paper summarizes public participation challenges from a social equity standpoint, and gives examples of some recent Latin American and other international initiatives which address these challenges and which have global relevance for equitable watershed decision-making.

\section{Public engagement challenges}

The substantial consensus among ecological economists, sociologists, political scientists, planners, and radical activists that public participation is essential for good public policy may obscure the vital question of how to elicit, structure, and make use of that participation. While in practice it sometimes seems difficult to organize or elicit public participation (a "bottom-up" problem), and in some cases governments are reluctant to cede control by opening up decision processes for public examination and input (a "top-down" problem), the theoretical reasons outlined above show that, at least in principle, broad public participation is the foundation of sustainable development. It also has a number of quite progressive implications - if it truly gives a political voice to people who have historically been left out of public decision-making. The way in which public participation processes are carried out, however, is a crucial determinant of their potential success.

What is to prevent public participation opportunities from taking status quo power differentials as a given, and then simply perpetuating or even exacerbating them? If that is so, why are more "open" processes necessarily better? Feminist political scientists have commented on this tendency, as have those working in international development contexts where internalized oppression and social violence are ever-present (Gujit and Shah, 1998; Naples, 1998; Lister, 1997; Cooke and Kothari, 2001; O'Hara, 1999; Armour, 1995; Fung, 2004; Kapoor, 2005). It is almost certainly not by chance that a groundswell of critiques of "public participation" is being led by authors and activists who are not white men.
Just as in the case of any social justice initiative, such as civil rights for blacks in the US 50 years ago, elites can and do strongly resist threats to their control of local politics. To the extent that higher-level government jurisdictions override subsidiarity ${ }^{3}$ and impose procedures which interrupt local power structures for environmental reasons (e.g. the European Water Framework Directive or Brazil's water law, which both require the participation of civil society in watershed management), there can be backlashes against the newly-recognized or created "participatory" bodies and/or against environmental and resource protection itself. The long time-frames and large scales often needed for environmental policy-making can heighten this friction between local elites (or global corporations) and participatory democratic priorities. When environmental impact analyses, with their participation requirements, are avoided through corporate pressure for "fast-track" approvals, this can cause serious and long-term ecological harm. In other words, top-down requirements for participation can backfire, hurting environmental protection goals in general. This is hardly a reason not to require and build participation processes which are enforced from above, but it is a caution and an indication that sensitivity and/or serious clout may be needed, and the processes may take time. Of course, even self-organized, grassroots participation can lead to backlash and temporary setbacks for long-term political and ecological goals.

Public participation processes can be very costly, and their outcomes can be hard to interpret and to integrate into multi-jurisdictional decision-making. They will never be as simple as a single cost-benefit analysis dollar figure or "bottom line." That, in fact, is part of their appeal - but when one or more political jurisdictions are spanned, incorporating the outcomes of public processes can be very difficult. Again, this is not a reason to give up, but another indication that design of the processes and laying supportive political groundwork is important.

Participation can also boomerang if it raises people's hopes about progressive change, only to dash them on the rocks of inter-jurisdictional squabbles or other difficulties in acting on the outcomes of deliberative democracy. This can lead to cynicism or worse. It is important that participants not be misled about the impact and implications of their involvement in deliberative processes.

Public participation depends on people who have the time and energy to participate, so it is almost inevitably class-biased and favours dominant cultures or ethnicities. The language in which meetings take place, time of day or day of the week, whether childcare, stipends, meals and transportation support are provided, and other such factors, can strongly influence who participates and who is effectively excluded. Structural factors which make it easier for some people to attend meetings are likely to make it harder for others to attend (Mansbridge in Fung:48), so this is not necessarily straightforward. Popular organizing and grassroots movements are not immune to these kinds of structural factors which can effectively exclude some people from participating.

Moreover, internalized oppression, group dynamics, racism/ prejudice and other factors can bias deliberative processes in the direction of elite interests even when no one is physically excluded (Fung:49; Karpowitz, 2003).

A more fundamental issue with formal and informal participatory processes is that often they leave the onus on development opponents to organize and resist environmentally-damaging decisions, rather than shifting the burden to demonstrate benefits outweighing costs onto those trying to get permission for new resource use and development. They thus are biased against applying the precautionary principle. How the participation process is

\footnotetext{
${ }^{3}$ Subsidiarity is the principle that government decisions should be made at the most decentralized level possible, by the lowest competent authority. It is a fundamental principle of European Union law.
} 
Table 1

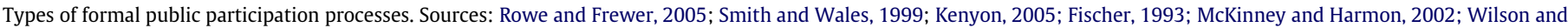
Howarth, 2002; Proctor and Dreschler, 2006.

Public meetings and hearings

"These mechanisms rely on the public to come to the information rather than vice versa. As such, the involved public is largely self-selected and biased in terms of those most proactive and interested. Information is communicated face-to-face by sponsors to those involved and is variable, depending to some degree (often small) on what participants ask. Public hearings are often required when some major government program is about to be implemented or prior to the passage of legislation; public meetings may be initiated by a local authority or convened in response to citizen concerns." (Rowe and Frewer, 2005, p. 278). There is no direct relation between public input and the decision-making process. "Information flow is one-way; there is no involvement of the public per se in the sense that public feedback is not required or specifically sought. When the public attempts to provide information, there are no mechanisms specified $a$ priori to deal with this at any level beyond, perhaps, simply recording the information." (Rowe and Frewer, 2005, p. 255)

\section{Citizens panels}

“The main example of this type (of process) is the standing citizens' panel (e.g. health panel). This is characterized by the choice of representative participants who meet in a facilitated group setting. Unlike a focus group, the panel may meet several times a year to debate different topics (i.e. views may be traced throughout time), with members rotated off after a while. At the end of meetings, opinions are usually aggregated via some form of vote/secret ballot. Consultations may also take place via mail (i.e. non face-to-face)." (Rowe and Frewer, 2005, p. 281). "Information is conveyed from members of the public to the sponsors of the initiative, following a process initiated by the sponsor. Significantly, no formal dialogue exists between individual members of the public and the sponsors. The information elicited from the public is believed to represent currently held opinions on the topic in question." (Rowe and Frewer, 2005, p. 255). Citizens panels may be quite large and have thousands of members; "they are used as a sounding board by a public sector organization on new policies, processes and innovations. The panels allow opinions and attitudes of participants to be tracked over time. Members are recruited to be a representative sample of the local population. Due to high attrition rates over time, new participants are recruited at regular intervals." (Kenyon, 2005, p. 440)

Citizens juries/planning cells

"A citizens' jury brings together a group of ... citizens to deliberate on a particular issue, whether it is the setting of a policy agenda or the choice of particular policy options. Over a number of days participants are exposed to information about the issue and hear a wide range of views from witnesses, who are selected on the basis of their expertise or on the grounds that they represent affected interests. With trained moderators ensuring fair proceedings, the jurors are given the opportunity to cross-examine the witnesses and, on occasion, call for additional information and witnesses. Following a process of deliberation among themselves, the jurors produce a decision or provide recommendations in the form of a citizens' report. Typically the sponsoring body (a government department, a local authority or other agency) is required to respond, either by acting on the report or explaining why it disagrees with it." The extent to which citizens' juries have influenced political decision-making processes has varied; in Europe they appear to be both more common and more influential than in North America, Australia, and other parts of the world. They serve in effect as a complement to representative democracy, not a substitute (Smith and Wales, 1999, p. 296; Kenyon, 2005, p. 435). Sometimes jurors are randomly chosen; sometimes they are "selected to represent a microcosm of their community" (Kenyon, 2005, p. 431). "In the case of planning cells - a German mechanism - these tend to use various decision aids to ensure structured consideration and assessment, and hence aggregation, of opinions" (Rowe and Frewer, 2005, p. 282)

\section{Multi-stakeholder committees/task forces}

These are "structurally similar (to citizens' juries) but with the difference that there is no facilitation of the information elicitation process. In many ways, they are simple group processes with no specific facilitation of input from group members or aggregation of opinions .... (They) use small groups of participants / public representatives, with ready access to all pertinent information, to solve specific problems.” (Rowe and Frewer, 2005, p. 281). Like citizens' juries and planning cells they are participatory, in the sense that "information is exchanged between members of the public and the sponsors. That is, there is some degree of dialogue in the process that takes place (usually in a group setting), which may involve representatives of both parties in different proportions (depending on the mechanism concerned) or, indeed, only representatives of the public who receive additional information from the sponsors prior to responding. Rather than simple, raw opinions being conveyed to the sponsors, the act of dialogue and negotiation serves to transform opinions in the members of both parties (sponsors and public participants)." (Rowe and Frewer, 2005, p. 255-256)

Discourse-based valuation

"The basic idea is that small groups of citizen-stakeholders can be brought together to deliberate on the economic value of a public good, and that the values derived in this forum can then be used to guide ... policy ... By implementing a fair and openly structured procedure for deliberation, it is assumed that small groups of citizens can render informed judgements about public goods not simply in terms of their own personal utility, but also in terms of widely held social values ... The role of the discursive process is, therefore, to help this social unit structure, learn about, and articulate preferences .... The group is not meant to negotiate, but rather to engage in a deliberative process for making consensus-based judgements. Because the process of deliberation requires citizens to go beyond private self-interest, it is further believed that the outcome will increase the social equity and political legitimacy of outcomes.... In this manner, the process of discourse itself is taken to provide a "corrective function for situations where individual citizens alone possess incomplete information. Acting together, groups can piece together a more complete, and socially just, assessment of ecosystem goods and services." (Wilson and Howarth, 2002, p. 432). "The purpose of discourse-based methods is, therefore, to reach agreement on what should be valued by or on behalf of society as a whole .... By exposing participantś initial preferences to one another through 'reasoned debaté, the logic goes, preferences may change and in this way, be brought closer together .... While this may not result in a complete convergence of values, compromise will still be achieved through a dialogue between competing judgments of the best interests of society as a whole, not a simple aggregation of individual preferences." (Wilson and Howarth, 2002, p. 436. See also Perkins, 2001; Perkins, 2003; Perkins, 2004b).

\section{MultiCriteria evaluation/multiattribute decision analysis}

"Multicriteria evaluation (MCE) is a well-tried and effective procedure for structuring and aiding complex decision-making processes, especially those involving environmental considerations. Formal deliberative processes have also been successful in aiding understanding and meeting consensus in complex and difficult decision problems which involve more than one decision maker .... Both approaches are combined in a new technique called 'deliberative multicriteria evaluation' ... This approach is an attempt to combine the advantages of MCE, providing structure and integration in complex decision problems, with the advantages of deliberation and stakeholder interaction provided by a 'citizens' jury' .... In general, the stakeholder jury ... (assists decision makers) in their understanding of the issues of a complex decision-making problem." (Proctor and Dreschler, 2006, p. 169) "Multiattribute decision analysis (MDA) has also recently been adapted as a group-based approach for evaluating and selecting land and water resource management systems. . Here, as with conventional MDA ..., the basic idea is that a given land area can be decomposed into an array of multiple attributes, each valued in its own metric (monetary or otherwise), which are then rearranged into alternative scenarios between which 'social decision makers are asked to make tradeoffs. Among other strengths noted in this recent literature, groupbased MDA need not limit itself to assigning monetary values to ecological services. Moreover, the approach circumvents the classical utilitarian view of optimality by avoiding several assumptions employed in conventional environmental accounting ..." (Wilson and Howarth, 2002, p. 437)

structured and constrained, and who bears the responsibility for challenging whom, is a crucial aspect of how they work.

Government-sponsored public engagement processes - where the terms and limits of the debate are set in advance by the authorities - are fundamentally more conservative than public deliberation in the context of community organizing or social movements, where the status quo assumptions are challenged and discussions reframed (Fung:51). Public participation and engagement, of course, takes place outside of government-established channels as well as within them, and participation in one form may help to educate leaders and activists and encourage participation in other forms (Fung:52). Conversely, government-organized referenda may undermine popular organizing efforts, partly by confusing people about the degree of the state's responsiveness 
to democratic demands (Zibechi, 2004, p. 10). And opportunities for participation within government-authorized processes may defuse and diffuse movement-based organizing for changes going beyond that which is controlled and sanctioned by the state.

Frameworks for understanding participation can thus apply both to "official" and to "unofficial" public engagement activities. To the extent that the interests of non-elite community members, women, racialized people, aboriginal people, and others who are traditionally excluded are actively protected or brought to the forefront by the way the process is structured, it is more likely to be a process with radical implications for changes in the status quo.

Opportunities for public involvement within official government channels can be structured in an infinite variety of ways (Rowe and Frewer, 2005). In discussing her experiences with participatory processes related to watershed management in Europe, Kenyon points out that citizens' Juries (and, by implication, all similar discourse-based valuation or decision can be problematic in several ways:

- Representation: what population should be represented? Should representation be broad, "symbolic," statistical, random, or intentionally skewed to give a "voice" to traditionally underrepresented groups? These questions are important in large, diverse areas where there are many complex and conflicting interests.

- Accountability: should panel members be accountable to their "constituents" (those they seek to represent); and should governments be required to act on panel decisions; if so, how? If the citizens' Jury is intended to make decisions but this effectively closes down further public discourse, this is crucially important to their political role.

- The role of experts: what is the power relationship implied by citizens Jury processes between "experts" and "ordinary citizens?" If the juries simply rubber-stamp priorities set out by "experts," this can lead to alienation and cynicism about the process itself.

- Scale: river basins can be extremely large geographic areas and can be difficult to define spatially. This can make a citizens Jury process nearly impossible to implement in practical terms.

- Time-frame: citizens' Juries tend to be short-term, one-off processes, while sustainable decision-making must consider the long-term. Water management in particular requires long time-frames and iterative decision processes; these can put great demands on citizen participants and demand high degrees of "institutional memory."

- Jurisdictional issues: watershed management generally requires collaboration across many political and institutional boundaries, so even if a participatory panel can be assembled, the implementation of its decisions throughout the watershed may be nearly impossible (Kenyon, 2003, pp. 4-10).

In addition, the degree to which the conclusions of the participatory process are acted upon by governments may vary widely. Citizens' juries are usually specifically empowered to consider a particular issue and provide recommendations to governments, with assurances those recommendations will play an important role in policy outcomes (Smith, 1999). Other processes, especially those which are not organized or sanctioned by governments, may have a more tenuous link with future policies.

Kenyon suggests that some possible ways of dealing with the difficulties noted above could include establishing "network juries" made up of various constituent or geographical representatives within a long-term time-framework, perhaps reporting to another participatory panel; or a "three-stage jury" comprising a traditional participatory panel, a stakeholder jury and an inter-jury forum; or a small-scale but long-term citizens' panel process; or a long-term "open jury" process where anyone could make presentations and the jury is part of a wider policy discourse process. Each of these proposals addresses some of the concerns listed above, but no single way has emerged to deal effectively with all of them. To some degree, complex participatory processes may in effect substitute for or create parallel structures to democratic governments. Does this let elected politicians and/or bureaucrats "off the hook" to represent the public interest? Does it allow special interests to carry the day, because no one else has the time or commitment to get involved? Or does it hold elected officials accountable by the oversight of a potentially even more democratic process than the one which elected them? Clearly the answers to these questions will depend on the specific situation, but they do point out the complexity of effecting democracy, in both practical and theoretical terms.

Nancy Fraser (1993) has outlined the exclusionary political struggles behind the constitution of the "public sphere," and the ways in which Habermasian deliberation can mask ongoing domination (1993, pp. 119-120). This is echoed by Gujit and Shah (1998), pp. 7-8). Kothari also concludes that self-styled public participation can help dominant groups to reassert their control and power, if people are brought into the process in a way that "disempowers them to challenge the prevailing hierarchies and inequalities in society" (2001, pp. 142-143).

Fraser, Kothari, Gujit and Shah, and Kapoor, as well as additional commentators Mouffe (1996) and Mosse (2001), all conclude however that a way forward lies in political organizing and participation by what Fraser calls "subaltern counterpublics" (1993, p. 126) who are able to set the terms of debate within spheres they control. Even Mouffe, despite her dismissal of the role of class, speaks of "radical and plural democracy"4 (1996, p. 248); Kapoor calls for "coordinated yet plural and flexible" institutions to "represent changing and diverse audiences" (2001, p. 275); Kothari points out that participation allows participants to subvert the process by resisting inclusion and choosing when not to participate (2001, p. 149). What emerges is a picture of participation which may segue or iterate between formal processes which are government-established (and controlled, to a greater or lesser degree) and informal, popular, grassroots organizing which influences and puts pressure on state systems.

Over this complicated socio-political picture, we must also layer additional complexities related to class, ecological and spatial issues. Bioregional and cultural/ethnic spatial boundaries that are different from political ones create a strong a priori impetus for the creation of new institutional frames for public participation and trans-jurisdictional environmental decision-making. Solving problems in airsheds and watersheds is a strong reason for people to talk with each other across political boundaries (Perkins, 2001). This lies behind the framing of the European Water Framework Directive (EWFD), and other water laws which use it as a model, such as the 1997 Brazilian water law: they establish trans-jurisdictional water basin committees with government and "civil society" representation to discuss and decide nearly all issues concerning water management in each watershed, including issues related to the collection of water fees and the use of the revenues collected for water-related infrastructure improvements and management. This is obviously an issue with global significance - for example, in Southern Africa, struggles related to the Lesotho Highlands Water Project and to droughts and flooding in Mozambique highlight the need for innovative and democratic trans-jurisdictional water management structures. These needs are heightened by cli-

\footnotetext{
${ }^{4}$ Mouffe and Laclau in fact use populism and what they call "new political subjects" (women, minorities, New Social Movements, etc.) to launch a critique of class politics; central to this is "discourse" and "democracy" (see Osborne, 1991, p. 203).
} 
mate change-related ecological pressures, and by poverty and international economic inequities.

To the extent that new, participatory institutional frameworks make possible more bioregionally-based governance, they may represent an improvement in an ecological sense (Perkins, 2004a). But the same equity caveats as noted above for any public participation process also apply. Moreover, the structure of many watershed management schemes has been set up to facilitate charging users for water use and infrastructure, because (at least in the EWFD and the Brazilian case) the water basin committees depend for revenues and expenditure-power on collecting fees from water users. How they collect and disburse these funds is up to them. Thus, governments have transferred the political responsibility for and fallout from instituting unpopular water charges to a separate agency, composed not of politicians but of "stakeholder representatives." The neoliberal impetus behind this clever rejigging is clear: an incentive structure has been created to, in effect, assemble a stakeholder body for instituting water fees, under the guise of ecological/bioregional management. These water committees have power to capture rents and spend them, but only if they are willing to face public ire about the implementation of water charges - thus protecting politicians from having to deal with this thorny issue through the normal state channels.

It would appear in some cases, therefore, that the creation of public participation processes is not motivated simply by a desire for better, purer democracy. The relationship between traditional political institutions and new participation-oriented structures merits close attention.

Like all words and concepts which can become co-opted, the power of "public participation" lies in its basic attractiveness as an idea. Of course people should have a say in public decisions which affect them; of course this is a vital component of sustainability; of course the more democracy the better. It is only when we delve into what "public participation" actually means in specific cases that certain difficulties and political contradictions become apparent. They include the following:

1. Is public participation meant to undermine or create parallel structures to the state? Why not just democratize the existing government more fully? Or when we say "public participation," do we really mean "enhanced voice and access in policy-making for a certain segment of 'the public'?" Such special processes have significant costs; early studies on the expenditures necessary to comply with European Water Framework Directive public participation guidelines indicate they may require hundreds of thousands of dollars annually (EU, 2001; EC, 2003). These costs, because they suck up general government revenues, arguably may represent inefficiencies, in light of the pressing needs everywhere for better public information and more broadlybased democracy.

2. The difficulties of getting people to actually become involved in public processes (see Abers, 2003) are seldom acknowledged. Why participate? Who has the time to attend community meetings, when it's not clear what difference it makes and it might be used by the powerful as legitimation, and there is no stipend or child care provided to assist citizens to attend? This clearly affects people differently according to class, gender, ethnicity and "race." When participation implies an open, voluntary process, it is almost guaranteed to attract special interests which are not generally reflective of overall public opinion or of public interest over the long-term.

3. To the extent that attendance and participation are encouraged through guarantees that the outcome will have an effect on public policy (e.g. the requirements of the Water Framework Directive or some citizens Jury processes), elected officials are, in effect, devolving responsibilities for policy decisions onto arm's-length or independent agencies. This raises legitimacy issues - are such bodies in fact more democratic or less?

4. The many equity concerns discussed above, related to who comes to the meetings, who speaks and is listened to, gender, ethnicity, and exclusion of particular viewpoints, are very problematic. For women and for the poor in particular, for example, water access is closely linked to quality of life, yet water committees do not reserve seats based on such subsistence concerns.

5. Instead, seats are generally reserved for government officials at various levels, water users, and/or "civil society," which usually in practice means selected NGOs - so the committees institutionalize a form of "stakeholder" politics, which is next door to "shareholder" politics. These are much less attractive words than "public participation," and indicate its potential, fundamentally anti-democratic tendencies.

6. Requirements for public participation processes (e.g. in aid projects or research grant proposals) reveals the extent to which this is an agenda item of globalized capitalism and a project which needs critical unpacking. Power is rarely on the side of broad-based democracy.

Nowhere is this cynical use of the term "public participation" clearer than in relation to water, the ultimate resource, fundamental for life. For example, a recent paper on watershed management in Nicaragua and the proposed institution of water charges notes that ecosystem degradation due to "development" has necessitated new efforts to put a value on ecosystem services and charge users for them in order to remediate the damage. Citing a 2002 World Bank study, the authors note, "It has been recognized that if implementing systems of payments for environmental services involves transfer payments from rich urban to poor rural households, they may also serve rural development objectives. This has clearly contributed to the popularity of the concept among development organizations" (Johnson and Baltodano, 2004, p. 58). In other words, water charges to raise money for fixing the ecosystem depredations of earlier "development" projects are being justified on the grounds that this will help the poor. But later in the paper, the authors recommend community-level mediation of rights to water through, for example, water committees and participatory water management (Johnson and Baltodano, 2004, p. 71). In Nicaragua, they report, these committees are a legacy of previous projects (undertaken in conjunction with NGOs, an earlier requirement of such development projects) where households provided free labour in return for connection to the spring-fed potable water systems. The community water committees were formed to manage the potable water projects, and some now handle broader water management issues (Johnson and Baltodano, 2004, p. 60). But if fundamental redistribution is the goal, be it of water access or income, how can a participatory local group realistically be expected to bring about this redistribution? Put bluntly, what is to force those better off to do anything that is not in their own interests? Like the earlier emphasis on NGOs, this current emphasis on public participation is doomed to failure without some mechanism to acknowledge and rectify previous power and money grabs by elites.

\section{Environmental education for equitable public engagement}

Governments and development organizations world-wide are searching for new ideas on how to bring more public participation into environmental policy decision processes. Some social and political movements, too, are expanding their participatory outreach and organizing techniques. In the Great Lakes region of North America, for example, various jurisdictions emphasize public 
involvement and participation in source water protection (CIELAP, 2004). The Council of Canadians, through its Blue Planet project and other organizing initiatives, seeks to focus public opinion globally on the importance of water rights (Council of Canadians, 2006). And as mentioned above, the European Water Framework Directive is pushing jurisdictions and cross-jurisdictional water basin committees to implement new participatory processes. Researchers, consultants and activists are generating practices which can be widely discussed and shared. But in the end, while many insights can come from hearing what worked and what did not in other places/situations, there is no substitute for locally-designed and locally-appropriate public participation processes, both within and outside of government.

As the conclusion of the European Water Framework Directive Guidance Document on Public Participation states, "The preamble of the Water Framework Directive includes a very clear statement: active public involvement is most likely the key to success with regard to achieving the desired water quality objectives." This statement reflects several years of accumulated European water management experiences. In simple words: the water users and water polluters need to be turned into part of the solution, not

kept outside the considerations as part of the problem. This Guidance has presented a range of recommendations on how to ensure active involvement. It is important, however, to take into account that no blueprint solution can be provided. Each River Basin District has to find its own way to handle this, taking into account the prevailing cultural, socio-economic, democratic and administrative traditions. Careful planning, e.g. stakeholder analysis, is a particular recommendation, but each competent authority has to accept that a dynamic and learning process based on "trial and error" is the challenge to embark on. Experience shows, however, that given sufficient time it will pay off in the long run" (EC, 2002b, p. 66). Like many official pronouncements, this document casts government initiatives in a very positive light and ignores issues such as in what sense water users who are unserved by infrastructure or too poor to pay for water are really "stakeholders," how the "payoff" of a public learning process might be measured, and to whom this payoff accrues.

In particular, the role of class and gender, among other differences, as determinants of everyone's standpoint and possibilities for participation must be acknowledged. Liberal individualism is certainly not the only thing going on in any participatory process. The truly radical nature of participation only appears as and when it leads to economic redistribution - not just policy-making within existing structures of distribution. ${ }^{5}$ Under capitalism and due particularly to its second, ecological, contradiction (O'Connor, 1994), the pressing need for local environmental knowledge and the contributions of diverse constituencies (Fischer, 1993, p. 182; McKinney, 2002, p. 3) in order to address ecological constraints has arguably loosened the controls which the state has traditionally placed on democracy. The type of policy analysis that is "antagonistic to authentic democratic participation" (Fischer, 1993, p. 182) is now giving way in some instances to more democratic policy-generating processes as a means of addressing intractable environmental problems. But the inherent open questions of gender, "race," ethnicity and class inequities remain.

To address both the "top-down" and the "bottom-up" challenges to broadening public involvement in watershed decision

\footnotetext{
${ }^{5}$ Osborne, Wood, Mouzelis and Miliband, among others, have written extensively about the structural limitations of democracy under capitalism. For example, Osborne notes, "Within capitalist societies, democracy is and has always been restricted to highly specific social spheres, and identified with a correspondingly narrow range of formal procedures. On this basis, and on this basis alone, is it compatible with private property in the means of production" (1991, p. 214). State restrictions on democracy, however, seem increasingly difficult to defend, which is what this paper attempts to explore.
}

processes as cited above, a creative combination of grassroots environmental education and community organizing is needed. Community-based environmental education initiatives which are relevant and interesting for local residents and increase their knowledge of watershed issues, understanding of basic political and ecological principles, and confidence to express their views can serve as the basis of an intervention approach which is progressive, constructive and democratic. This, in turn, increases the resilience and sustainability of watershed decision-making processes. It also lays the groundwork for community organizing and extension of the environmental education activities to larger constituencies in local areas affected by watershed decisions.

As an example of how this can work in practice, I would like to outline the process and results of the Sister Watersheds project, with which I have been involved over the past 5 years (see www.baciasirmas.org.br and www.yorku.ca/siswater). The Sister Watersheds project linked universities and NGOs in Canada and Brazil in developing strategies and materials for increasing the knowledge, interest and engagement of local residents on water-related issues, focusing on low-income neighbourhoods in São Paulo and Toronto and, in particular on low-income women. Funded by the Canadian International Development Agency through the Association for Universities and Colleges of Canada, this \$1.3 million project combined student exchanges, research, community engagement, and capacity-building. Its novel conceptualization and design were developed by progressive Brazilian environmental educators Dr. Marcos Sorrentino (a professor at the University of São Paulo who was subsequently appointed director of environmental education in the Brazilian federal Ministry of the Environment) and Larissa da Costa of the Ecoar Institute for Citizenship, who subsequently became environmental education director at the World Wildlife Fund in Brasilia. The project's design evolved throughout its implementation by organizers at the Ecoar Institute, including Débora Teixeira, Mariana Ferraz Duarte, and Miriam Duailibi.

While Brazil has a progressive watershed management system requiring participation by civil society representatives on its watershed committees, low-income people and women in particular are underrepresented - despite their being those most likely to be affected by water-related issues and problems (Moraes and Perkins, 2007). Addressing this gap, which of course has parallels in every country including Canada, was a primary challenge for the Sister Watersheds project.

The Sister Watersheds project developed and tested training programs by conducting workshops led by its local NGO partners with more than 1450 participants (roughly two-thirds of them women), partnering with other community organizations to present content on topics related to environmental education and watershed management. For example, staff from the Ecoar Institute for Citizenship, an environmental education NGO based in São Paulo, contacted groups of elementary teachers, public health extension agents, and other community-based workers and provided in-service training for them about water and health, basic ecology, and public policy questions related to water in their local communities. The various training programs were shaped and modified to be specifically appropriate for groups of children, youth, health agents, school groups, teachers, film/culture/music/arts organizations, and Agenda 21/environmental education groups. The workshops focused on water management, environmental education, community development, and democratic participation, with emphasis on gender and socio-economic equity. The methodologies, techniques, and materials developed for these workshops and training programs were made freely available to other organizations through publications and websites, as well as contributing to the capacity of project partner organizations and individual staff members and students to continue related work on watershed policy issues into the future. 
The curriculum materials and techniques developed by the project were tested and fine-tuned in more than 220 workshops designed and led by project staff and exchange students in the three watersheds. All of the workshop participants were potential participants in Brazil's watershed committees, as civil society representatives/organizers. The curriculum materials developed by the project include a 110-page illustrated Manual on Participatory Methodologies for Community Development containing a set of workshop activities and background materials for participatory community environmental education programs and training sessions focusing on water issues; a 47-page illustrated guide with practical exercises focusing on urban agroecology; a full-colour socio-environmental atlas which brings together ecological, hydrological and social information about one local watershed in a series of interactive maps; a video about the history and environment of this watershed; a publication outlining Agenda 21 activities in schools; and several blogs and websites with materials and discussion-starters on watershed topics, as well as a book and many journal articles, masters' papers, and other academic publications contributing to the literature on participatory watershed education in Brazil.

Project participants from the University of São Paulo, York University in Toronto, and the Ecoar Institute for Sustainability - both continuing staff members and students, and those who have moved on after working on the project - benefitted from the opportunity to develop skills related to project proposal development, project implementation, financial management, environmental education and training, community development, communications, website development, mapping, video-making, public engagement and liaison with government officials, along with many other project-related skills. The project partners continue to make use of these experiences in their ongoing development of new projects, as well as their assistance to other organizations which, through the Sister Watersheds project, have come to see them as experts and leaders on watershed management issues.

The community environmental perception surveys conducted by the project in each of the Brazilian watersheds established a database of information on public priorities and views on watershed issues. The socio-environmental atlas gathered and made available in one place a wide range of information on ecological, hydrological, social and political circumstances in the watershed as a whole - information which proved very useful to public officials and watershed committee members in understanding the watershed as a whole. The nearly 1500 participants in workshops conducted by the project gained familiarity and experience with water-related issues and their own ability to influence water management and policy through watershed committee structures, community organizing, community arts, and other means.

This project helped both its university and NGO participants to bridge the gap between academic and community-based methods of environmental education. Graduate exchange students studied and contributed to local training programs; faculty members wrote about the theoretical and practical benefits of public participation in watershed management; NGOs supervised students who received academic credit for their community-organizing work; professors led local watershed governance structures; innovative methods for environmental education were shared internationally; this collaboration allowed new perspectives on water management to evolve, with benefits for all participants' training/education programs. USP, York and Ecoar developed at least 38 new partnerships with other community organizations as a result of this project.

Students, both in Brazil and in Canada, played a crucial role in developing the linkages between academic institutions and community-based NGOs. Both locally and internationally, students sought out community organizations for their research and field experiences, and shared the results of their work with both academic and non-academic audiences. The student exchanges of this project thus fuelled its interdisciplinary and educational bridging contributions.

Besides the dozens of staff and students involved in the project directly through its partner organizations, the participants in workshops run by the project, and the audiences at the many public seminars organized by the project and the conferences where its results were presented, the project's outreach includes those using its websites (more than 10,000 hits were recorded on the baciasirmas.org.br website in 1 month in 2006) and the curriculum materials and publications it has generated. These audiences include people from academia, government, NGOs, and local communities/civil society. So there is potential for tremendous multiplier effects from such interventions designed to train trainers on water issues and generate workshop materials and techniques for progressive community engagement, disseminating the results through both activist and academic channels.

Other examples of grassroots organizing leading to popular education with implications for watershed management include the establishment of Constituent Assemblies and "open schools" in Cochabamba, Bolivia prior to Bechtel's ouster as water company there (Olivera, 2004), and the development of an open university by the Brazilian Landless Movement (MST), with an environmental and political focus based in the "pedagogy of land" (Fuchs, 2004).

\section{Transnational organizing for creative public engagement}

Another very inspirational and transnational model for intervention to increase public involvement in watershed management is one being developed by the Socio-Environmental Knowledge and Care Centre of the La Plata Basin (Centro de Saberes), an organization funded largely by a fraction of the hydroelectric power revenues generated by the huge Iguaçu dam, located on the Paraná River where Brazil meets Paraguay and Argentina (centrodesaberes@pti.org.br; http://www.saberycuidar.org/home/).

The Paraná watershed, which drains much of central and eastern South America and reaches the Atlantic ocean via the La Plata River near Montevideo, also includes Bolivia and Uruguay, so the Centro de Saberes works in three languages - Portuguese, Spanish and Guaraní, the official language of Paraguay. The Centro de Saberes convenes semi-annual "permanent learning circles" attended by media, academic, activist and political representatives of each of the five countries in the watershed. Each year, like ripples, the "permanent learning circles" expand, as the participants from the year before invite additional representatives to attend in subsequent years. The circles have grown from five participants (one from each country) in 2006, the first year, to 35 the next year, to hundreds currently. The agenda and program of the meetings include social exchanges among participants, discussions of local priorities for environmental and political action, and brainstorming about how to accomplish the goals identified by each group.

The Centro de Saberes has five operating principles: water as the generator theme; the La Plata watershed as the operating territory; an ethic of protection of the diversity of life in the watershed and consideration of the different kinds of knowledge and protection available in the watershed; environmental education as an element capable of engaging society into action; and the collective construction of information, knowledge, and actions.

In places where computers are readily accessible even by marginalized populations, online techniques can also be effectively used to disseminate information about watersheds and their management. An example is the Water Atlas (http://www.wateratlas.usf.edu), a website portal developed by Dr. Paul Zandbergen 
and others at the University of South Florida. It brings together hydrological, weather, political, and other data related to a number of Florida watersheds with the goal of designing a "comprehensive data resource... to help citizens and scientists alike make informed decisions concerning our vital water resources." Such online materials may also be translated to be accessible transnationally across bioregional boundaries.

\section{Conclusion}

There are many good reasons to develop ever-better participatory processes. These processes must be locally appropriate and specific in their details; they must involve all members of the community concerned with the outcome or decision; they must consider long-term political and ecological implications; they must grapple with the difficult issues of scale, jurisdictions, time-frame and scientific uncertainty.

While this paper has detailed a number of critiques of "public participation" in theory and in practice, I think it is also very important not to lose sight of its potential impact as a radical tool for education, empowerment and voice for previously-marginalized people. Whether it is via new organizations of "subaltern counterpublics" or through selective non-participation, or whether education and organizing related to public participation processes bring new social groups into the broader political process in some way, I believe it's very possible for public participation processes to serve as a vehicle for deepening democracy and for progressive social and political change.

The more inclusive is the welcoming and effective expression of new voices within public participation processes, the more radical is this potential. This is not because popularly-driven decisions and outcomes must be or always are radical, but rather because truly including a broad spectrum of public viewpoints in political and environmental decision-making is itself inherently and fundamentally radical. As academics, activists, and people concerned about improving public policy, we must continually seek out the best, fairest, most effective and widest-ranging ways in which this can be done.

\section{References}

Abers, Rebecca Neaera, 2003. Reflections on what makes empowered participatory governance happen. In: Fung Archon, Wright, Erik Olin (Eds.), Deepening Democracy: Institutional Innovations In Empowered Participatory Governance. Verso, London.

Aldred, Jonathan, Jacobs, Michael, 2000. Citizens and wetlands: evaluating the ely citizens' jury. Ecological Economics 34, 217-232.

Armour, Audrey, 1995. The citizens' jury model of public participation: a critical evaluation. In: Renn, O., Webler, T., Wiedermann, P. (Eds.), Fairness and Competence in Citizen Participation. Kluwer, Dordrecht, pp. 175-187.

Caddy, Joanne, 2005. Evaluating Public Participation in Policymaking. Organization for Economic Cooperation and Development, Paris.

Christian Aid, 2005. Unearthing the Truth: Mining in Peru. London: Christian Aid Report, February. <www.christianaid.org.uk> (accessed 26.10.06).

CIELAP, 2004. Public Participation in Great Lakes Management. Canadian Institute for Environmental Law and Policy, Toronto.

Cooke, Bill, Uma, Kothari (Eds.), 2001. Participation: The New Tyranny? Zed Books, London/New York.

Council of Canadians, 2006. Blue Planet Project. <http://www.blueplanetproject. net/Movement/index.html>. <http://www.canadians.org/>

Davies, Wetherell, Barnett, 2006. Citizens at the Centre: Participation in Health Care Decisions. Policy Press, UK (October)

De Marchi, B., Funtowicz, S.O., Lo Cascio, S., Munda, G., 2000. Combining participative and institutional approaches with multicriteria evaluation. An empirical study for water issues in Troina, Sicily. Ecological Economics 34, $267-$ 282.

De Marchi, Bruna, Funtowicz, Silvio, Pereira, Angela Guimarães, 2001. From the right to be informed to the right to participate: responding to the evolution of European legislation with ICT. International Journal of Environment and Pollution 15 (1), 1-21.

EC, 1993. Towards Sustainability: The European Community Programme of Policy and Action in Relation to the Environment and Sustainable Development (Better Known as The Fifth EC Environmental Action Programme). The EC Europa
Website. <http://europa.eu.int/comm/environment/actionpr.htm> (accessed 09.07.04).

EC, 2000. Directive 2000/80/EC Establishing a Framework of Community Action in the Field of Water Policy. EC Website. <europa.eu.int/eur-lex/pri/en/oj/dat/ 2000/1_327/1_32720001222en00010072.pdf> (accessed 09.07.04).

EC, 2002a. Environment 2010: Our Future, Our Choice. The Sixth Environment Action Programme of the European Community. EC Website. <http:// europa.eu.int/comm/environment/newprg/> (accessed 09.07.04)

EC, 2002b. Guidance on Public Participation in Relation to the Water Framework Directive: Active Involvement, Consultation, and Public Access to Information. EC Circa Website. <http://forum.europa.eu.int/Public/irc/env/wfd/library?l=/ framework_directive/guidance_documents/ participation_guidance \&vm=detailed\&sb=Title> (accessed 10.07.04).

European Communities (EC), 2003. Common Implementation Strategy for the Water Framework Directive (2000/60/EC), Guidance Document No. 8: Public Participation in Relation to the Water Framework Directive. Working Group 2.9 - Public Participation. Luxembourg.

European Union (EU), 2001. Guidance on Public Participation in Relation to the Water Framework Directive, Active Involvement, Consultation, and Public Access to Information. <http://forum.europa.eu.int/Public/irc/env/wfd/ library?l=/framework_directive/guidance_documents/ participation_guidance\&vm=detailed\&sb=Title>.

Faucheux, Sylvie, Hue, Christelle, 2001. From irreversibility to participation: towards a participatory foresight for the governance of collective environmental risks. Journal of Hazardous Materials 86, 223-243.

Fischer, Frank, 1993. Citizen participation and the democratization of policy expertise: from theoretical inquiry to practical cases. Policy Sciences 26, 165187.

Fraser, Nancy, 1993. Rethinking the public sphere: a contribution to the critique of actually existing democracy. In: Calhoun, Craig (Ed.), Habermas and the Public Sphere. MIT Press, Cambridge, Massachusetts.

Fuchs, Erika Del Carmen, 2004. Living Dreams: Creating Revolutionary Educational Environments - The Political Education of the Brazilian Landless Rural Workers Movement (MST). MES Major Paper, Faculty of Environmental Studies, York University: Toronto.

Fung, Archon, 2004. Deliberation's darker side: six questions for Iris Marion Young and Jane Mansbridge. National Civic Review 93 (4), 47-54.

Gedicks, Al. 2005. Mining War in Ecuador. Z Magazine. March.

Gregory, Robin, Slovic, Paul, 1997. A constructive approach to environmental valuation. Ecological Economics 21, 175-181.

Gujit, Irene, Shah, Meera Kaul (Eds.), 1998. The Myth of Community: Gender Issues in Participatory Development. Intermediate Technology Publications, London.

Holland, Alan, 1997. The foundations of environmental decision-making International Journal of Environment and Pollution 7 (4), 483-495.

Innes, Judith, Booher, 2004. Reframing public participation. Planning Theory and Practice 5 (4).

Johnson, Nancy L., Baltodano, Maria Eugenia, 2004. The economics of community watershed management: some evidence from Nicaragua. Ecological Economics $29,57-71$

Kapoor, Ilan, 2001. Towards participatory environmental management? Journal of Environmental Management 63, 269-279.

Kapoor, Ilan, 2005. Participatory development, complicity and desire. Third World Quarterly 26 (8), 1203-1220.

Kapoor, Ilan, 2008. The Postcolonial Politics of Development. Routledge, London \& New York.

Karpowitz, C.F., 2003. Public Hearings and the Promise of Deliberative Democracy. Paper Presented at the American Political Science Association Meetings, Philadelphia, PA, August 28-31.

Kenyon, Wendy, 2003. Environmental Planning: Scientific-Political Decision Processes, Participatory Decision Processes. In: Presented at the Frontiers 2 Conference of the European Society for Ecological Economics, Tenerife, Canary Islands, February 11-15. <http://wwwleuroecolecon.org/frontiers/Contributions/contributions.html>.

Kenyon, Wendy, 2005. A critical review of citizens' juries: how useful are they in facilitating public participation in the EU water framework directive? Journal of Environmental Planning and Management 48 (3), 431-443.

Kothari, Uma, 2001. Power, knowledge and social control in participatory development. In: Cooke, Bill, Uma, Kothari (Eds.), Participation: The New Tyranny? Zed Books, London.

Lister, Ruth, 1997. Citizenship: Feminist Perspectives. NYU Press, New York.

McKinney, Matthew, Harmon, W., 2002. Public participation in environmental decision making: is it working? National Civic Review 91 (2), 149.

Moraes, Andrea, Perkins, Patricia E, 2007. Women, equity, and participatory water management in Brazil. International Feminist Journal of Politics (4) (Fall)

Mosse, David, 2001. People's knowledge participation and patronage operations and representations in rural development. In: Cooke, Bill, Uma, Kothari (Eds.), Participation The New Tyranny. Zed Books, London.

Mouffe, Chantal, 1996. Democracy, power, and the "political". In: Benhabib, Seyla (Ed.), Democracy and Difference. Contesting the Boundaries of the Political. Princeton University Press, Princeton.

Munda, Giuseppe, 1995. Multicriteria evaluation in a Fuzzy environment: theory and applications in ecological economics. Physica-Verlag, Heidelberg.

Nagel, Jack, 1987. Participation. Prentice-Hall, Englewood Cliffs, NJ.

Naples, Nancy A. (Ed.), 1998. Community Activism and Feminist Politics: Organizing Across Race, Class and Gender. Routledge, New York/London. 
O'Connor, James, 1994. Is sustainable capitalism possible? In: O'Connor, Martin (Ed.), Is Capitalism Sustainable? Guilford Press, New York, pp. 152-175.

O'Connor, Martin, 2000. Pathways for environmental evaluation: a walk in the (hanging) gardens of Babylon. Ecological Economics 34, 175-193.

O'Hara, Sabine, 1999. Economics, ecology and quality of life: who evaluates? Feminist Economics 5 (2), 83-89.

Olivera Oscar, Tom Lewis, 2004. Cochabamba! Water Rebellion in Bolivia. South End Press.

Osborne, Peter, 1991. Radicalism without limit? Discourse, democracy and the politics of identity. In: Osborne, P. (Ed.), Socialism and The Limits of Liberalism. Verso, London/New York.

Perkins, Patricia E, 2004a. Women, Public Participation, and Environmental Valuation. Paper Presented at the Conference of the International Association for Feminist Economics (IAFFE), St. Hilda's College, Oxford University, UK, August 4-7.

Perkins, Patricia E., 2004b. Public Participation and Ecological Valuation. Paper Presented at the Conference of the International Society for Ecological Economics (ISEE), Montreal, Canada, July 10-14

Perkins, Patricia E., 2003. Public Participation in Ecological Valuation: How Policies Can Help it Happen, Paper Presented at the Conference of the Canadian Society for Ecological Economics (CANSEE), Jasper, Alberta, October 16-19.

Perkins, Patricia E., 2001. Discourse-Based Valuation and Ecological Economics. Paper Presented at the Conference of the Canadian Society for Ecological Economics (CANSEE), McGill University, Montreal, Canada, August 23-25.

Proctor, Wendy, Dreschler, Martin, 2006. Deliberative multicriteria evaluation. Environment and Planning C: Government and Policy 24 (2), 169-190.

Renn, Ortwin, Webler, T., Wiedemann, P., 1995. Fairness and Competence in Citien Participation. Kluwer Academic Publishers, Norwell, MA.

Rowe, Gene, Frewer, Lynn J., 2005. A typology of public engagement mechanisms. Science technology and Human Values 30 (2), 251-290.

Sagoff, M., 1998. Aggregation and deliberation in valuing environmental public goods: a look beyond contingent pricing. Ecological Economics 24, 213-230.
Sanders, Lynn, 1997. Against deliberation. Political Theory 25 (3).

Smith, Graham, 1999. Theory and practice of citizens' juries. Policy and Politics 27 (3).

Smith, Graham, Wales, Corrine, 1999. The theory and practice of citizens' juries. Politics and Policy 27, 295-308.

Steenbergen, Bart Van, 1994. The Condition of Citizenship. Sage Publications.

UN, 1992. Report of the United Nations Conference on Environment and Development (Rio de Janeiro, 3-14 June), UN Document No. A/CONF.151/26 (vol. I), found on the UN website. <http://www.un.org/documents/ga/conf151/ aconf15126-1annex1.htm> (accessed 08.07.04).

van den Hove, Sybille, 2000. Participatory approaches to environmental policymaking: the European commission climate policy process as a case study. Ecological Economics 33, 457-472.

van den Hove, Sybille, 2003. Between Consensus and Compromise: Acknowledging the Negotiation Dimension in Participatory Approaches. Presented at the Frontiers 2 Conference of the European Society for Ecological Economics, Tenerife, Canary Islands, February 11-15. <http://wwwleuroecolecon.org/ frontiers/Contributions/contributions.html>.

Wilson, Matthew A. Howarth, R.B., 2002. Discourse-based valuation of ecosystem services: establishing fair outcomes through group deliberation. Ecological Economics 41, 431-443.

World Bank, 1996. World Bank Participation Sourcebook. World Bank, Washington, DC.

Young, Iris Marion, 2000. Inclusion and Democracy. Oxford University Press, Oxford/New York.

Zapatistas in Cyberspace: A Guide to Analysis and Resources, 2003. <http:// www.eco.utexas.edu/faculty/Cleaver/zapsincyber.html> (accessed 13.10.06).

Zibechi, Raúl, 2004. Privatizations: The End of a Cycle of Plundering. Global Policy Forum, Americas Forum, November 1. <http://www.globalpolicy.org/globaliz special/2004/1101 privatization.htm>. 